\title{
Thermal Image Thresholding for Automatic Detection of Bovine Mastitis
}

\author{
Rodes Angelo B. da \\ Silva \\ Doctoral Student \\ Department of \\ Agricultural Engineering \\ UFRPE/Recife, PE
}

\author{
João Paulo Silva do \\ Monte Lima \\ Professor, Department of \\ Computing, \\ UFRPE/Recife, PE
}

\author{
Héliton Pandorfi \\ Professor of the \\ Agricultural Engineering \\ Department \\ UFRPE/Recife, PE
}

\author{
Gledson Luiz P. de \\ Almeida \\ Professor of the \\ Agricultural Engineering \\ Department \\ UFRPE/Recife, PE
}

\begin{abstract}
Disruptive technologies are of great relevance for the advancement of animal science. Dairy cattle farming is of uttermost importance in the global scenario, but hindrances such as mastitis have been causing losses in the sector. This study aimed to develop and validate an algorithm for thresholdbased segmentation of thermal images and automatic classification of clinical cases of bovine mastitis. The research was conducted at two milk production units located in the municipalities of Capoeiras and Pesqueira, Pernambuco, Brazil. The number of samples was determined according to the selection criteria and totaled 120 animals (40 healthy animals, 40 animals with subclinical mastitis, and 40 with clinical mastitis). Thermal images of the animals' udder were made with an infrared thermographic camera; the shots were taken from the front left, front right, rear and lower mammary quarters, with four images per animal, totaling 960 thermal images for analysis of said quarters. For automatic segmentation of images, an algorithm in C++ language was developed using the OpenCV library to identify the temperature referring to each pixel on the image through interpolation by the technique of pixel thresholding and quantification in the analyzed interval ( $\mathrm{t}$ to tmax) of each image . Healthy animals presented 11,034 to 21,521 pixels. Animals with subclinical mastitis presented 12,582 to 40,032 pixels. In those with clinical mastitis, pixels ranged from 45.223 to 49.451. The algorithm for automatic segmentation allowed distinguishing the images of healthy animals from those of animals with subclinical and clinical mastitis. The routine implemented for determining the temperature of each pixel on the image was coherent, derived from results obtained through Flir Tools software.
\end{abstract}

\section{Keywords}

Image analysis, dairy cattle breeding, thermal imaging

\section{INTRODUCTION}

The adoption of new technologies is of great importance in advancing animal science. Currently, one of the challenges in this area involves determining reliable means for measuring the general status of animals [3].

Dairy cattle farming is an activity of major relevance in the global scenario, but hindrances such as mastitis have been causing losses in the sector. The economic impact of its occurrence on milk production systems gathers a set of factors responsible for damages, flock productive losses, costs associated with treatment for clinical cases, discards and premature death of animals, loss of quality and industrial yield of milk in natura and its by-products. [5].
Mastitis is an inflammation resulting from contagious or environmental pathogens that colonize cow teats during the lactation period and manifests in clinical and subclinical forms.

In its clinical form, signs are perceptible and usually include sensitivity to touch on the udder and changes in milk characteristics. In its subclinical form, signs are imperceptible, and it can be detected by means of practical on-field or laboratory tests [11].

Noninvasive exams such as infrared thermography (IRT) can be used for obtaining reliable data as it generates thermal images or thermograms, through which it is possible to therefore assess and determine the physiological and/or pathological meaning of a temperature variation on the surface of an animal's udder [3].

Early detection of symptoms is essential for a more efficient management of the challenge that mastitis in dairy cattle is. As a result, most researches addressing health detection are based on surface temperature measurements using thermal cameras $[21][14][16][8][10]$. Bovine mastitis can be detected based on udder surface temperature variation before the first clinical signs appear [11][4][18][5].

From the moment a digital image is obtained, computational vision allows extracting information through protocols of operations and/or transformations, which may result in a new image representation until signs and patterns that help in decision making processes are obtained [7]. In this context, image segmentation consists of dividing an image into a set of pixels based on the similarity shared by the pixels of said image. The identification of image sections based on pixels with similarities in terms of intensity values constitutes thresholdingbased methods. Studies like those by [17] and [20] used segmentation of thermal images with emphasis on early diagnosis of diseases, achieving satisfactory results.

Thus, this study aimed to develop and validate an algorithm for thresholding-based segmentation of thermal images and automatic classification of clinical cases of bovine mastitis.

\section{RELATEDWORK}

\subsection{Acquisition of images}

The research was conducted at two milk production units located in the municipalities of Capoeiras $\left(8^{\circ} 36^{\prime} 33^{\prime}\right.$ ' S latitude, $36^{\circ} 37^{\prime}$ $30^{\prime}$ W longitude and altitude of $733 \mathrm{~m}$ ) and Pesqueira (Latitude: $8^{\circ} 21^{\prime} 35^{\prime \prime}$ South, Longitude: $36^{\circ} 41^{\prime} 42^{\prime \prime}$ West, $652 \mathrm{~m}$ ), Agreste Mesoregion, Microregion of Vale do Ipojuca, state of Pernambuco, Brazil.

The average rainfall in the region is $588 \mathrm{~mm}$ per year, with average annual temperature of $22.1^{\circ} \mathrm{C}$. According to the Köppen climate classification, the climate of the region is characterized 
as Bsh, semiarid [22].The number of samples was determined according to selection criteria - animals with same birth order, lactation stage, body score, production, blood group - and

The animals' clinical condition was established by the California Mastitis Test (CMT), before milking (after the first milk gushes were discarded), because it is when milk fat content is low and does not interfere with the CMT score visual results. The test was run for each mammary quarter, with the attribution of scores ranging from 0 to 5 ; at score 0 , no precipitate formed (healthy); at score 1, there was a light precipitate (infection trace); at score 2 , there was moderate precipitate (subclinical mastitis); at score 3, there was a clear precipitate, but without gel formation (subclinical mastitis); at score 4, there was a clear gel formation (subclinical mastitis); and at score 5, there was a pronounced gel formation (subclinical mastitis). To limit subjectivity in interpretation of results, only scores 2 to 5 were considered for selection of animals with subclinical mastitis.

To detect clinical mastitis cases, the 'dark-bottomed mug' test was run. It allowed noticing visible changes in the milk (lower secreted volume, lumps, pus, or aqueous aspect). In addition, the animals were checked for sensitivity to touch on the udder and teats due to an inflammatory case.

Thermal images of the animals' udder were taken with an infrared thermographic camera - resolution of $0.01^{\circ} \mathrm{C}$, focal length of 1.0, and emissivity adjusted to 0.98 [5]. The images were taken in the morning, before the first milking, between 05:00 and 07:00, at the first place, of the front left quarter, front right quarter, rear quarter and lower quarter, with four images per animal -, and then again at 10:00 and 12:00, at the second place, where shots of the rear and lower quarters were taken. For the other quarters (left and right front sides), no image was taken because, at the second place, the milking parlor had a structure that only allowed making images of the rear and lower mammary quarters, totaling 360 thermal images for analysis (Figure 1).

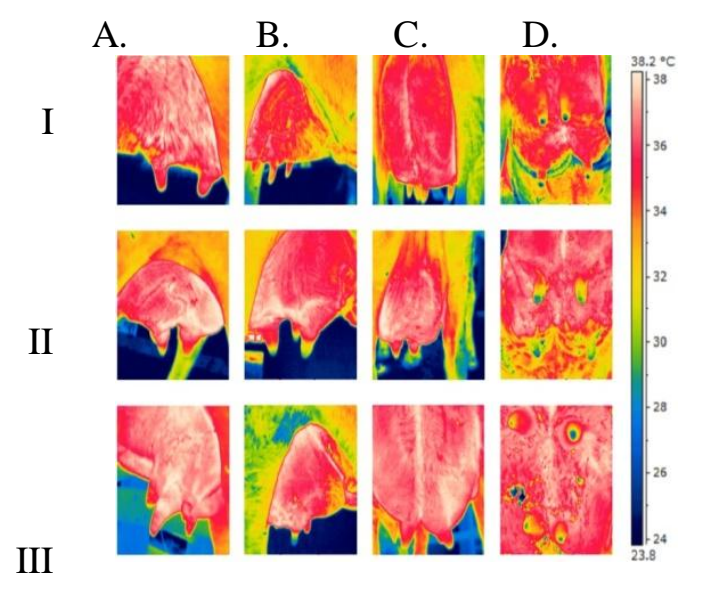

Figure 1. Thermal images referring to the clinical pictures and perspectives used in the analysis

The thermal images were visually analyzed using the FlirQuickReport@ program, with adjustment of the emissivity, ambient temperature and relative humidity values obtained at the time the images were recorded. Meteorological variables (ambient temperature and relative humidity)were recorded using a HOBO U12-12Datalogger. totaled 120 animals (40 healthy animals, 40 animals with subclinical mastitis, and 40 with clinical mastitis).

\subsection{Descriptive statistics}

First, the mammary quarters (anterior right, left, posterior left and right) were analyzed using descriptive statistics to observe the temperature variation between the rooms of the different clinical pictures (mean, median, standard deviation, coefficient of variation, kurtosis and normality) The criterion adopted to determine the coverage area of each mammary quarter was developed from a Cartesian plane measuring $2.4 \times 0.75 \mathrm{~mm}^{2}$, adopting a spacing of $5 \mathrm{~mm}$ for each pixel, referring to the surface temperature values for the composition in the selected area, disregarding the edges; thus, a $25 \times 80 \mathrm{~mm}$ matrix was generated with 102 sampled points (Figure 2).।

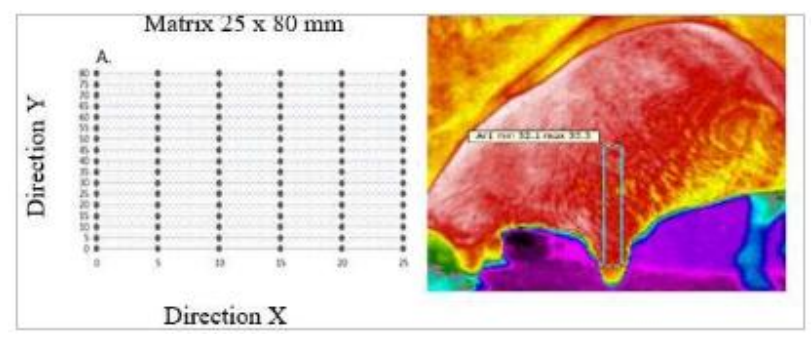

Figure 2. Sampling grid with $X$ and $Y$ coordinates with 102 points $(A)$ referring to the surface temperature of the selected area (B) on the mammary quarter

\subsection{Image analysis}

For automatic image segmentation, the images were converted to shades of gray (figure 3).

For automatic image segmentation, an algorithm in language $\mathrm{C}++$ was developed using OpenCV, a multiplatform library used for processing images. This algorithm aims to provide the temperature referring to each pixel of the image through interpolation (Eq. 1).

$$
t=\frac{t \max -t \min }{255} * C+t \min (1)
$$

in which:

$\mathrm{t}$ - threshold $\left({ }^{\circ} \mathrm{C}\right)$;

tmax - maximum interval of temperature on the image $\left({ }^{\circ} \mathrm{C}\right)$;

tmin - minimum interval of temperature on the image $\left({ }^{\circ} \mathrm{C}\right)$; $\mathrm{C}-($ tave $-\mathrm{tmin}) /((\mathrm{tmax}-\mathrm{tmin}) / 255.0)$;

In image segmentation, an image is divided into a set of areas based on similar resources shared by the pixels of said image. The process consists of segregating the image into sections in order to perform tasks on the segmented area [6]. The identification of image sections based on pixels with similarities in terms of temperature values constitutes the basis of the thresholding method.

[9] defines thresholding as an operation that involves tests of a T function of the form (Eq. 2).

$$
T=f(x, y, p(x, y))(2)
$$

in which $\mathrm{f}(\mathrm{x}, \mathrm{y})$ is the level of gray at the point $(\mathrm{x}, \mathrm{y})$ and $\mathrm{p}(\mathrm{x}$, $\mathrm{y})$ denotes a local property of said point. A thresholded image $\mathrm{g}(\mathrm{x}, \mathrm{y})$ is defined as (Eq. 3). 
$g(x, y)=\{1$ iff $x, y>T ; 0$ iff $x, y<T(3)$

Therefore, pixels labelled as 1 (or any other convenient level of gray) correspond to the background, while those labelled as 0 correspond to the temperature from $t$ to tmax. When $T$ depends only on $\mathrm{f}(\mathrm{x}, \mathrm{y})$, the threshold will be called global. If $\mathrm{T}$ depends on both $f(x, y)$ and $p(x, y)$, then the threshold will be called dynamic. To validate the algorithm, comparisons were made between the temperatures obtained through the algorithm and the results obtained by software Flir Tools. Function CountNonZero was used for counting elements zero of the matrix. Interpolation takes into consideration the upper and lower limits of the image (tmax and tmin), with $t$ being the temperature to be determined. In this case, black pixels represent temperatures in the range from $t$ to tmax. White pixels comprehend temperatures in the interval from tmin to $t$.

\section{RESULTSANDDISCUSSION}

When checking the values of the descriptive statistics of the mammary quarters, differences were observed between the clinical pictures.

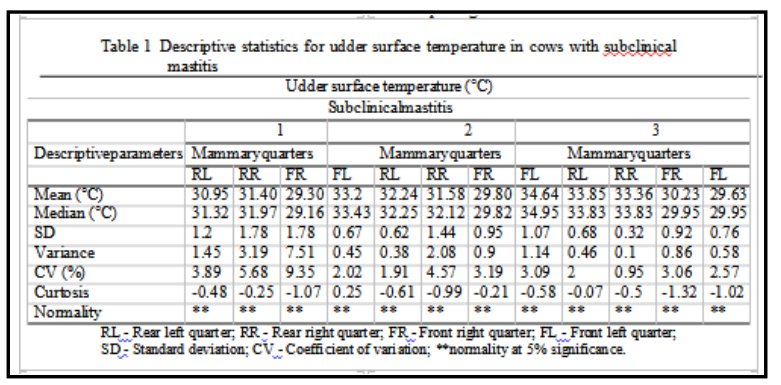

The average temperatures on the surface of the mammary quarters with subclinical mastitis (score 5) were: $34.64^{\circ} \mathrm{C} \pm$ 0.67 (front left side), $33.85^{\circ} \mathrm{C} \pm 0.68$ (rear left side) and $33.36^{\circ} \mathrm{C} \pm 0.32$ (rearight side), respectively (Table 1 ). Negative mammary quarters presented temperatures ranging from $29.3^{\circ} \mathrm{C} \pm 1.78$ to $31.58^{\circ} \mathrm{C} \pm 0.62$ (Table 2). According to Polat et al. (2010), quarters with sub- clinical mastitis presented a surface temperature $2.35{ }^{\circ} \mathrm{C}$ higher than that of healthy quarters. However, the values found were $35.80^{\circ} \mathrm{C}$ for quarters with mastitis, and $33.45^{\circ} \mathrm{C}$ for healthy quarters, diverging from the values found in this study -5.3 to $4.55^{\circ} \mathrm{C}$ above the surface temperature of healthy udders. [2] reported temperatures lower than those found by [13] for subclinical mastitis. Udder temperature variation magnitude is associated with infection stage and room temperature during thermal image capturing.

With respect to the analyzed images, there was a higher occurrence of animals with mastitis on the front left quarter (FL); the temperature of these quarters presented a higher mean, smaller variation, with the coefficient of variation $(\mathrm{CV}$, $\%$ ) indicating low variability and smaller standard deviation values, followed by the rear left quarter (RL), the front right quarter (FR), and the rear right quarter (RR). According to [18] a $\mathrm{CV}<15 \%$ indicates low variability.

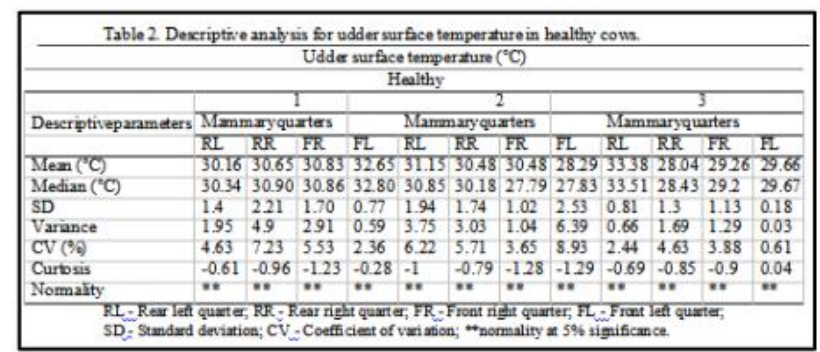

The animals classified with clinical mastitis had an average udder surface temperature of $37.58 \pm 0.33 \mathrm{C}$ to $37.11 \pm$ $0.61^{\circ} \mathrm{C}$ (Table 3). Mammary quarters with clinical mastitis presented higher temperatures when compared to those quarters with subclinical mastitis and healthy ones (Tables 1 and 2). Values for coefficients of variation indicated low variability (Warrick\& Nielsen, 1998), and so did the standard deviations. Kurtosis values were negative, indicating a less steep normal distribution curve. This allows inferring that the evolution of the infectious case raises the udder surface temperature with a reduction in data spatial variability.

Animals classified as having clinical mastitis presented average udder surface temperature of $37.58 \pm 0.33^{\circ} \mathrm{C}$ to $37.11 \pm 0.61^{\circ} \mathrm{C}$ (Table 3). Mammary quarters with clinical mastitis presented higher temperatures when compared to quarters with subclinical mastitis and healthy ones (Tables 1 and 2). Values for coefficients of variation indicated low variability [23].

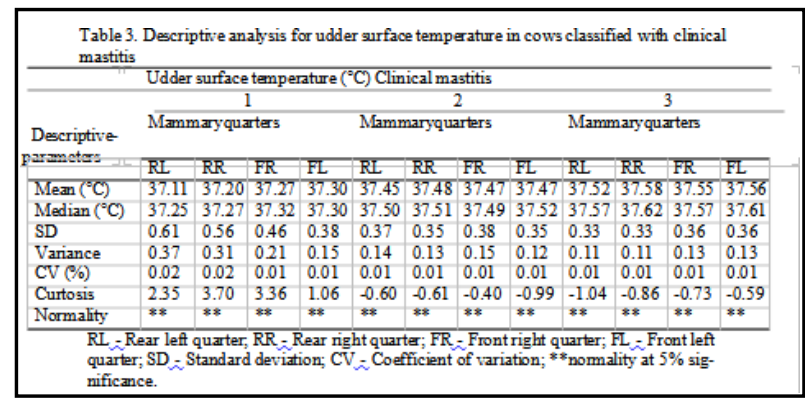

The algorithm for automatic segmentation allowed selecting a few areas on the thermal image that were associated with values above the threshold, within the interval from 34 to $38.6{ }^{\circ} \mathrm{C}$. Specific representative values below the threshold, from 13 to $34{ }^{\circ} \mathrm{C}$, were selected as well (Figure 3). Thus, it was possible to compare the methodology used and software Flir Tools of the thermal camera.

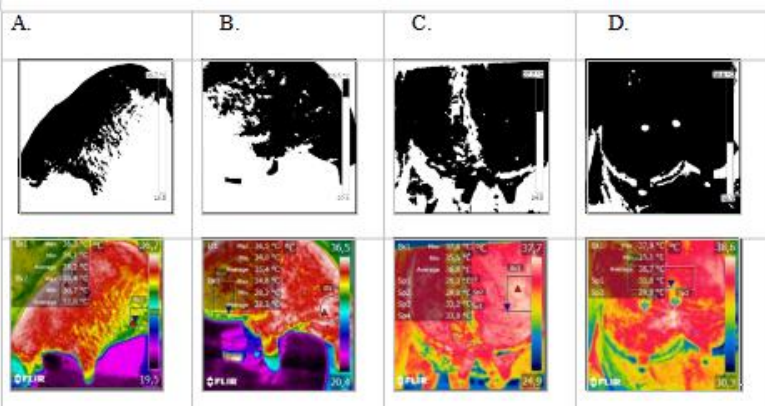

Figure 3. Images obtained by the algorithm for segmentation and thermal images used for validation through software Flir Tools for the front right quarter (A), front left quarter $(B)$, rear quarter $(C)$ and lower quarter (D)

On the thermal images, temperature variation is indicated based on a color palette. The udder area with predominance of red over white indicates high temperatures $\left(34\right.$ to $38.6{ }^{\circ} \mathrm{C}$ ). Thermal changes on biological bodies, such as those of the animals used, by means of thermal images, allow checking the degree of smoothness as to the transition of a color, frequency, into another, which allows identifying an inflammation condition.

Studies like those by [17], [6], [1] and [20] proved the efficiency of the thresholding method for use thermal images, with emphasis on early diagnosis of cancer and for counting somatic cells in bovine milk, by means of images obtained directly from an optical microscope. 
Image segmentation for different clinical cases allowed determining the area referring to pixels 0 (interval from 34 to $38^{\circ} \mathrm{C}$ ) in order to distinguish images of healthy animals, and of animals with subclinical and clinical mastitis, through function CountNonZero of OpenCV (Figure 4).

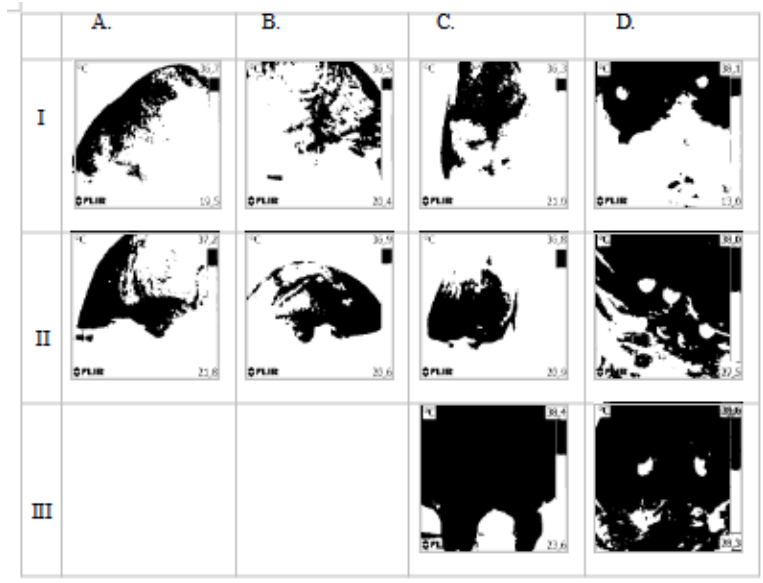

Figure 4. Segmentation result based on temperature $t=34$ C for healthy animals (AI,BI, CI, DI), animals with subclinical mastitis (AII,BII,CII,DII) and animals with clinical mastitis (CIII, DIII)

Healthy animals presented variation from 11,034 to 13,570 pixels above the threshold for rear quarters (Figure 5CI), 12,940 to 13,113 for front right quarters (Figure $5 \mathrm{BI}$ ), 10,345 to 11,279 for front left quarters (Figure 5AI), and 20,345 to 21,521 for lower quarters (Figure 5DI). These values correspond to 19.15 to $37.36 \%$ of the total of pixels of the image (240x240).

For cases of subclinical mastitis, there was variation from 12,582 to 15,678 pixels on the rear quarters (Figure 5CII), 13,433 to 14,567 for front right quarters (Figure 5BII), 13,456 to 14,532 for the front left quarters (Figure 5AII), 38,791 to 40,032 for lower quarters (Figure 5DII). The percentage representation varied from 21.84 to $69.5 \%$ of the total of pixels $(57,600)$

In animals with clinical mastitis, the average of pixels ranged from 45,223 to 46,487 for the rear quarters (Figure 5CII). For the lower quarters, it ranged from 48,824 to 49,451 (Figure 5DIII). The percentage representation varied from 78.5 to $85.85 \%$ of the total of pixels. Studies such as that by [15] found quarters positive for subclinical mastitis with surface temperature $2.35^{\circ} \mathrm{C}$ higher than that of healthy quarters.

The criteria for validating the thresholding technique presented an accuracy of $86.57 \%$, sensitivity of $83.45 \%$, and specificity of $60.4 \%$; the factors that most influenced the process of distinguishing images based on clinical condition were image capture angle, operator's position and environment influence, because the images were obtained at different places, hours, and on different days.

\section{CONCLUSIONS}

The algorithm for automatic segmentation by thresholding automatically identified the temperature of each pixel, which allowed classifying clinical cases of mastitis in dairy cattle. The verification of the performance of the segmentation technique for thermal images, based on software Flir Tools, presented good results.

Image capture angle, operator's position and image capture time were deemed as factors that interfered with the process of distinguishing the images; it was possible to improve the validation criteria of the adopted technique by attenuating these external disturbances.

\section{REFERENCES}

[1] Baffa, M.F.O., Cheloni, D.J.M., Lattari, L.G.and Coelho, M.A.N.(2016). Segmentação Automática de Mamas em Imagens infravermelhas utilizando limiarização com refinamento adaptativo em bases multivariadas. Revista de Informática Aplicada, 12(2)

[2] Bortolami, A., Fiore, E; Gianesella, M., Corro, M., Catania, S. And Morgante, M. (2015). Evaluation of the udder health status in subclinical mastitis affected dairy cows through bacteriological culture, somatic cell count and thermo graphic imaging. Polish Journal of Veterinary Sciences, 18(4), 799-805.

[3] Chacur, M.G.M,, Souza, C.D., Andrade, I. B., Bastos, G.P., Deak. F.L.G., Souza, M.G.R., Cornacini, G.F., Marques Júnior, A.P. (2016). Aplicações da termografia por infravermelho na reprodução animal e bem-estar em animais domésticos e silvestres. Revista Brasileira de Reprodução Animal, Belo Horizonte, 40(3), 88-94.

[4] Colak, A., Polat, B., Okumus, Z., Kaya M., Yanmaz, L.E., Hayirli, A. (2008). Short communication: early detection of mastitis using infrared thermography in dairy cows. Journa of Dairy Science, 91(11), 4244-4248.

[5] Digiovani, D. B., Borges, M.H.F., Galdioli, V.H.G., Matias, B.F., Bernardo, G.M., Silva, T.R.; Fávaro, P.C.; Júnior, F.A.B., Lopes, F.G.; Júnior, C.K. and Ribeiro, E.L.A. (2016) Infrared thermography as diagnostic tool for bovine subclinical mastitis detection. Revista Brasileira de Higiene e Sanidade Animal., 10(4): 685-692.

[6] Duarte, A., Carrão, L., Espanha, M.,Viana, T., Freitas, D., Bártolo, P., Faria, P., (2014). Tecnologia. 16, 1560-1569.

[7] García, G. B. et al. Learning Image Processing with OpenCV. [S.1.]: Packt Publishing Ltd, 2015

[8] Gloster,J.,Ebert,K., Gubbins, S.,Bashiruddin, J. andPaton, D.J. (2011) Normal variation in thermal radiatedtemperatureincattle:implicationsforfoot-andmouthdisease detection. BMC Veterinary Research, 7, 1746-6148.

[9] Gonzalez, Rafael C., Woods, Richard E. Processamento de Imagens Digitais. Edgard Blücher Ltda, 2000.

[10] Hoffmann, G., Schimdt, M., Ammon, C., Rose-Meierhofer, S., Burfeind, O., Heuwiese, W., Berg, W. (2013). Monitoring the body temperature of cows and calves using vídeo recordings from an infrared thermography camera. Veterinary Research Communications, 37(2) 91-99.

[11] Hovinen, M., Siivonen, J., Taponen, S., Hanninen, L., Pastell, M., Aisla, A.M., Pyorala, S. (2008). Detection of clinical mastitis with the help of a thermal camera. Journal of Dairy Science , 9(12), 4592-4598.

[12] Langoni, H., Salina, A., Oliveira, G.C., Junqueira, N.B.,Menozzi, B.D. and Joaquim, S.F. (2017). Consideraçõessobreotratamentodasmastites.PesquisaVeteri náriaBrasileira,37(11),1261-1269.

[13] Melo,G.J.A.,Neto,B.A.M.,Gomes, V.,Almeida, L.A.L. and Lima, A.C.C. (2014). Método de limiarização automática para a contagem de células somáticas em imagens microscópicas. Revista GEINTEC.4(3),1283 -1291. 
[14] Montanholi, Y.R., Odongo, N.E., Swanson, K.C., Schenkel, F.S., Mcbride, B.W., Miller, S.P., Application of infrared thermography as an indicator of heat and methane production and its use in the study of skin temperature in response to physiological events in dairy cattle (Bos taurus). (2008) Journal of Thermal Biology, 33(8).468-475.

[15] Polat, B., Colak, A., Cengiz, M., Yanmaz, L.E., Oral, H., Bastan, A., Kaya, S.; Hayrirli, A. (2010). Sensitivity and specificity of infrared thermography in detection of subclinical mastitis in dairy cows. Journal Dairy Science. Source: Journal of dairy science. 93(8), 3525-3532.

[16] Rainwater-Lovett, K., Pacheco, J.M., Packer, C., Rodriguez, L.L. (2009). Detection of foot-and-mouth disease virus infected cattle using infrared thermography. The Veterinary Journal , 180(3), 317-324.

[17] Resmini, R., Conci, A., Borchartt, T.B., De Lima, R.C.F., Montenegro, A.A., Pantaleão, C.A.(2012). Diagnóstico precoce de doenças mamárias usando imagens térmicas e aprendizado de máquina. Revista eletrônica do Vale do Itajaí, 1(1), 55-67.

[18] Redaelli, V., Bergero, D., Zucca, A, E., Ferrucci, F.,
Nanni, L., Crosta, L., Luzzi, F. (2013). Use of Thermography Techniques in Equines: Principles and Applications. Journal of Equine Veterinary Science, 1(6).

[19] Sá, J.P.N., Figueiredo, C.H.A., Neto, O.L.S., Roberto,S.B.A.,Gadelha,H.S.andAlencar,M.C.B..(2018).Re vista Brasileira deGestão Ambiental,12(1),01-13,2018.

[20] Shaikh, S., Manza, R., Hanumant, G., Kale, K. (2016). Segmentation of Thermal Images Using ThresholdingBased Methods for Detection of Malignant Tumours, International Journal of Intelligent Systems Tecnologies and Applications,330, 131-146.

[21] Schaeffer, A.L., Cook, N., Tessaro, S.V., Deregt, D., Desroches, G., Dubeski, P.L., Tong, A.K.W., Godson, D.L. (2004). Early detection and prediction of infection using infrared thermography. Can. J. Anim. Sci. 84 (1), 73-80.

[22] Vianello, R. L. And Alves, A. R. (1991). Meteorologia basic aeaplicações. Viçosa:UFV-Imprensa Universitária. 449p.

[23] Warrick,A.W.and Nielsen, D.R.(1998).Spatial variability of soil physic properties in the field. NewYork:Academic, 655-675. 